\title{
Effects of regulatory changes in microcredit on the financial and social performance of Brazilian credit unions
}

\author{
Ana Lucia Carvalho Santos ${ }^{1}$ \\ (D) https://orcid.org/0000-0003-1116-5292 \\ Email: analucia@uefs.br
}

Lucas A. B. C. Barros²

(D) https://orcid.org/0000-0002-9319-1306

Email: lucasbarros@usp.br

\author{
Tony Takeda ${ }^{3}$ \\ (D) https://orcid.org/0000-0002-5981-766X \\ Email: tony.takeda@bcb.gov.br \\ Lauro Gonzalez ${ }^{4}$ \\ (D) https://orcid.org/0000-0001-9316-6525 \\ Email: lauro.gonzalez@fgv.br
}

\begin{abstract}
${ }^{1}$ Universidade Estadual de Feira de Santana, Departamento de Ciências Sociais Aplicadas, Feira de Santana, BA, Brazil
${ }^{2}$ Universidade de São Paulo, Faculdade de Economia, Administração e Contabilidade, Departamento de Contabilidade e Atuária, São Paulo, SP, Brazil

${ }^{3}$ Banco Central do Brasil, Divisão de São Paulo, Departamento de Estudos e Pesquisas, São Paulo, SP, Brazil

${ }^{4}$ Fundação Getulio Vargas, Escola de Administração de Empresas de São Paulo, Centro de Estudos em Microfinanças e Inclusão Financeira, São Paulo, SP, Brazil
\end{abstract}

Received on 02.18.2018 - Desk acceptance on 03.05.2018 - 2nd version approved on 08.17.2018 - Ahead of print on 02.18.2018 Associate Editor: Fernanda Finotti Cordeiro Perobelli

\begin{abstract}
This study investigates whether the performance of credit unions that offer microcredit in Brazil was affected by the advent of Crescer - the National Microcredit Program. This research fills a gap in the literature because few papers investigate credit unions that work with microcredit and also the effects of governmental interventions related to microcredit operations. Studies of this type may help evaluate the impact of governmental interventions on the performance of the institutions that are directly or indirectly affected. Our results add to the debate about microcredit and about the inclusion of credit unions in this market. In particular, our evidence may influence the design of public policies and the strategies of microfinance institutions, which typically combine economic and social objectives. Based on the literature, we calculate fifteen indicators for each credit union, related to their financial and social performance. The inferences are based on the implementation of the difference in differences estimator using the advent of Crescer, in 2011, as the exogenous event of interest and including in the control group the credit unions that did not provide microcredit loans throughout the sample period. This research presents evidence that the volume of clients and microcredit operations performed by Brazilian credit unions was positively affected by regulatory changes that took place in 2011 , consistently with the objectives of the governmental intervention. The evidence also suggests that the governmental intervention did not harm the financial sustainability of the credit unions. The main changes are: a substantial reduction of interest rates and transaction costs, the implementation of subsidies to participants in the program, and a push for public banks to enhance their supply of productive and oriented microcredit.
\end{abstract}

Keywords: microfinance, bank accounting, public policy, credit unions, performance indicators.

Correspondence address

Ana Lucia Carvalho Santos

Universidade Estadual de Feira de Santana, Departamento de Ciências Sociais Aplicadas

Avenida Transnordestina, s/n - CEP 44036-900

Novo Horizonte - Feira de Santana - BA - Brasil 


\section{INTRODUCTION}

The microfinance segment covers all financial services aimed at the low income population, such as insurance, credit cards, saving, and microcredit, which is historically the most important among them (Aghion \& Morduch, 2005; Barone \& Sader, 2008).

Microcredit in Brazil is conceived in the context of the public policies for development and poverty reduction, and is considerably influenced by the regulatory and institutional environment and by specific governmental initiatives (Miguel, 2012). Among the most relevant of these are the National Oriented Productive Microcredit Program (NOPMP) and Crescer - the National Microcredit Program. In particular, the Crescer program, implemented in August 2011, introduced significant changes in the regulatory and institutional environment for short-term credit, stipulating a relevant reduction in interest rates and the opening credit rate (OCR) the final borrower is charged, establishing compensatory subsidies for institutions that adhered to the program, and creating microcredit provision targets for the public banks [Banco do Brasil (BB), Banco do Nordeste do Brasil (BNB), Banco da Amazônia (BASA), and Caixa Econômica Federal (CEF)].

The aim of this research is to investigate the influence of the regulatory and institutional environment for microcredit on the performance of the credit unions involved with this activity, focusing as a laboratory on the impacts of the adoption of Crescer. It is argued that the governmental intervention has the potential to significantly affect the social and financial performance of relatively small microcredit providing institutions, as is the case of credit unions, due to its impacts on the profile of the borrowers of microcredit and on the costs and revenues structure.

The studies in Brazil and the international ones that investigate the effects of regulation over the performance of microfinance institutions (MFIs) have grown considerably (Cull, Demirgüç-Kunt \& Morduch, 2008; Morduch, 1999). However, most (e.g., Christen \& Rosenberg, 2000; Lauer \& Staschen, 2013; Macchiavello, 2012; Martins, Winograd \& Salles, 2002; Meagher, 2002; Rosales, 2000) address regulation in an abstract way, discussing whether MFIs should be regulated or not, or discussing "good practices" for regulation, from a normative perspective.

This paper differs from previous ones by investigating the impact of a specific governmental intervention in the microcredit segment, also not evaluated in academic studies, over the performance of credit unions. For this, a new database was built, originating from the Brazilian Central Bank (CB) and containing microdata related to all the credit unions in the country in the period from 2008 to 2014. Besides contributing to the academic debate, the results of the research may interest regulators directly, providing new information from the perspective of the institutions involved, which may be useful in terms of evaluating and improving microcredit policies and programs.

The empirical strategy explores the advent of the Crescer program as a natural experiment that directly and indirectly covers the subset of credit unions that work with microcredit. Credit unions that are comparable, but that do not work with microcredit, are used as a control group, and the effects of the regulatory changes are estimated in difference in differences models. The conditions that enable causal inferences and the limitations of "quasi-experimental" strategies, such as that used in this research, are discussed, for example, in Shadish, Cook, and Campbell (2002). In the microfinance and microcredit segment, various studies have adopted similar strategies with the aim of identifying causal effects (Cozarenco \& Szafarz, 2014; Ledgerwood, 1999). Yet, as far as we know, the application of this strategy to investigate the performance of credit unions is unprecedented.

The results suggest that the performance of the credit unions that work with microcredit was significantly affected by the changes associated with the advent of the Crescer program, especially in its social dimension. Considering the breadth of coverage indicators of the credit unions, a significant increase in the number of clients served is documented, as well as the number of credit operations carried out, possibly as a response to the governmental intervention, in a way that is compatible with the program's stated objectives. A reduction in the average value of credit operations is also observed, which is evidence that is compatible with a concentrated expansion in microcredit operations. In contrast, there is no evidence of any impact of the program over the ratio between the quantity of operations and the number of clients. This result is not compatible with increasing the depth of coverage, a dimension that is related to serving the "poorest among the poorest" (Bassem, 2009; Conning, 1999; Hartarska, 2005).

There is no evidence that the quality of the credit portfolio has deteriorated as a result of the event in question. The results suggest that its influence over the default rate of the credit unions is insignificant, despite 
the growth in credit operations and in the number of clients, as well as the reduction in the average value of the operations. In the profitability dimension, there is evidence that the volume of credit grew more quickly than the income from credit operations, a result that is compatible with charging borrowers lower interest rates. On the other hand, the estimated effect of the changes is not significant for six other profitability indicators, including return on assets (ROA) and return on net equity (ROE), suggesting that the changes in the regulatory and institutional environment for microcredit did not clearly affect the financial sustainability of the credit unions. In accordance with this inference, the estimates suggest more rapid growth in the operating revenues in comparison with the operating expenses of the credit unions as a result of the event. Considered altogether, the evidence is compatible with an expansion in microcredit on the part of the credit unions, though carried out cautiously, without compromising the financial sustainability of these institutions and without necessarily reaching the lowest income borrowers, although the data do not allow for this last conjecture to be tested directly.

The rest of the text is structured in the following way: section 2 presents the overview of microfinance and credit unions; section 3 describes NOPMP/Crescer and their possible influence over the performance of credit unions; section 4 presents the design of the empirical research; section 5 presents, analyzes, and discusses the results of the study; and, finally, section 6 presents the paper's concluding remarks.

\section{MICROFINANCE AND CREDIT UNIONS}

Microfinance consists of the provision of financial services in general: savings, insurance, as well as credit in all its modalities (consumption, housing etc.) for the low income population and for microentrepreneurs. Microcredit is one of the products of microfinance and refers to all the credit modalities offered to this same public. According to Soares and Melo Sobrinho (2008), productive and oriented microcredit is that which is directed exclusively toward productive activities, excluding credit for consumption.

For Gonzalez, Righetti, and Di Serio (2014), the successful microcredit programs already studied indicate the existence of specific characteristics, which are: (i) the use of a solidary group, also known as joint liability; (ii) strong female participation; (iii) a focus on poor regions. These characteristics of microcredit and microfinance, also called methodologies or technologies, are what differentiate contemporary experiences of microcredit from older ones. Joint liability consists of a loan in groups of three or more members in which one backs the other, thus creating co-responsibility within the group, since non-payment of the loan by any of the members compromises the group as a whole. This mechanism not only substitutes the real guarantees but also monitoring of the loan, since the borrowers themselves take responsibility for this, instead of the institution. In addition to these technologies are the innovations related to information and communication technology (ICT), indicated by Gonzalez, Diniz, and Pozzebon (2015) as drivers of new microfinance business models, which should contribute to the challenge of reconciling development and profits in what has been conventionally called inclusive finance.
One example of these innovations is the operation of Banco do Nordeste do Brasil (BNB), which carries out many of its microcredit operations via the post office, which drastically reduces transaction costs (Littlefield, Morduch \& Hashemi, 2003).

Microcredit technologies were created and disseminated based on the experience of Grameen Bank. Although group lending have seen a rapid expansion since the start of the 1970s, through the work of the United Nations (UN) in Brazil, and of Grameen Bank in Bangladesh, this concept dates back to the 19th century (Bastelaer, 2000). The author attributes the origin of this technology to the credit unions created by Raiffeisen, in Germany, in the middle of the 19th century, which became known as "banks of the people", especially for practicing group lending whose criteria were: residency in small rural communities, a guarantee by the members, and coresponsibility of the colleagues for the loans (Bastelaer, 2000). Another microfinance technology relates to progressive loans or dynamic incentives, which consist of granting increasing loans conditioned on repayment of previous ones (Neri \& Medrado, 2010). In the case of default, the loans are not renewed. This possibility of non-renewal works as an incentive for payment.

The institutional environment for microfinance has its own logic and differentiated institutions. Microfinance institutions are defined by Morduch (1999) as specialized financial institutions (FIs), united under the banner of microfinance, which share the commitment to work toward financial inclusion. Ledgerwood (1999) refers to these as financial services providers to the poor, especially credit and saving. 
Specifically regarding credit unions, these differ from other FIs in terms of decision making, according to Railienè and Sinevičienè (2015). Thus, while the typical FI aims to increase shareholder value, credit unions enable a return for their members by providing financial services in more favorable conditions because they simultaneously have economic and social objectives.

The relevance of credit unions for microfinance is highlighted by Ward and McKillop (2005), who consider that the specific characteristics of this type of institution contribute to reducing information asymmetry, enabling them to provide loans in a way and in places that other FIs cannot, thus making them a potential instrument of financial inclusion.

Credit unions in Brazil resemble some specific types of MFIs because they do not seek profit. At the same time, they have similarities with conventional banks because they are, besides the banks, the only type of FI that is legally authorized by the CB to collect deposits (cash or term) from the public. Thus, they present a suitable institutional format for providing financial services to poor populations, since they are not for profit, at the same time as performing the role of financial intermediary. Another aspect that differentiates credit unions from other types of FIs is the fact that they constitute a local structure that combines activities of a financial and social nature, as well as presenting organizational characteristics based on mutuality and self-management, which enable the selection and monitoring of credit, also reducing operating costs (Schroder, 2005).

As the main aim of microcredit and microfinance is to reach the poorest, credit unions play a potentially important role as they spread throughout the entire country, even reaching the most distant and least economically privileged municipalities.

\section{NOPMP/CRESCER AND THE PERFORMANCE OF CREDIT UNIONS}

Considered as the most recent change in the Brazilian microfinance sector, the NOPMP is classified by the Ministry of Employment as a job and income creating program and it is considered as both an economic policy (it aims to create jobs and income) and a social policy (it is aimed at the poorest layers of society: the unemployed, underemployed, self-employed, individual microentrepreneurs, and microenterprises).

According to the NOPMP Law - Law n. 11,110, of April $25^{\text {th }}$ of 2005, the aims of the program are: (i) to incentivize the creation of jobs and income among common microentrepreneurs; (ii) to make resources available for oriented productive microcredit (OPC); and (iii) to offer technical support to OPM institutions, aiming to strengthen these institutions to provide mainstream entrepreneurial services. For the Ministry of Employment, OPM is the granting of credit aimed at small scale, formal and informal productive activities developed by individuals and companies, with an annual gross income of up to 120 thousand reais. The law foresees the monitoring of the operation by a credit agent who is properly trained for this role.

Within the scope of the NOPMP, the maximum value of credit is two thousand reais for individuals and five thousand reais for microentrepreneurs. The maximum opening credit rate allowed is $2 \%$ for individuals and $3 \%$ for microentrepreneurs. The interest charged is, at most, $2 \%$ a month. For OPM, one of the lines of the NOPMP, the limit for granted credit is up to 15 thousand reais, with an opening credit rate of up to $3 \%$ a month and interest rate of up to $4 \%$ a month. Only OPM foresees the monitoring of a credit agent [Law n. 11,110, of April $25^{\text {th }}$ of 2005, Provisional Measure n. 543 (August 25 $5^{\text {th }}$, 2011), Law n. 12,613, of April $18^{\text {th }}$ of 2012 (April 19 ${ }^{\text {th }}$, 2012), Law n. 12,666, of June $14^{\text {th }}$ of 2012 (June $15^{\text {th }}$, 2012), Ordinance n. 411 (June $17^{\text {th }}, 2013$ ), Ordinance $n$. 83 (March 31 ${ }^{\text {st }}, 2014$ )]. In 2011, the NOPMP underwent changes that resulted in the creation of Crescer - the National Microcredit Program. Crescer, considered as an expansion of the NOPMP, was launched via Provisional Measure n. 543 (August 25 ${ }^{\text {th }}, 2011$ ), subsequently made into law as part of the urban productive inclusion actions of the Secretariat for Economic Policy (SPE) of the Treasury Ministry, aiming to promote the emancipation of the beneficiaries of the Brazil Without Misery program. According to the SPE (2012), the general aim of the program is to raise living standards and create jobs within the context of Brazil Without Misery and, specifically: (i) to give an opportunity to new businesses; (ii) to encourage entrepreneurialism; and (iii) to encourage bank usage. The Crescer program was regulated by Resolution n. 4,000 of the $\mathrm{CB}$ (CB, 2011).

For the purposes of the program, the concept of OPM was defined as credit for entrepreneurs with a gross annual income of up to 120 thousand reais (the same range established by the NOPMP). The beneficiaries can be private individuals, individual entreprepreneurs, or microenterprises. The value of the operations is up to 15 
thousand reais, the average timeframe is 6 months, and they can be targeted at working capital or investment. The methodology adopted by the Crescer program is: (i) a direct relationship with the entrepreneurs in the place of the economic activity; (ii) a service provided by trained people (credit agents); (iii) permanent contact for monitoring and orientation; (iv) evaluation of the borrower's activity and capacity for debt. Regarding the guarantees, three modalities were established: joint liability for lower value operations; the goods themselves acquired in the lower value operations and targeted at investments; or, also, third-party guarantee. The federal public banks were strongly recommended to convert their consumption microcredit portfolios into OPM, with a reduction in interest from $60 \%$ a year (p.a.) to $8 \%$ p.a. The OCR was reduced from $3 \%$ to $1 \%$.

Thus, the project was, initially, run by federal public banks (BASA, BB, CEF, and BNB), which had targets to be met in relation to the number of active clients -2.24 million for 2012 and 3.46 million for 2013 - and to the total active portfolio - 1.73 billion reais in 2012 and 2.99 billion reais in 2013 (SPE, 2012). However, subsidies could be granted by the National Treasury to any FI that operated within the conditions defined for the program and agreed with the equalization (compensation) values defined by the Treasury Ministry. With this, it was hoped that the program would also be run by private institutions, thus increasing the volume of resources available and the number of entrepreneurs benefiting. The funding is the same as the NOPMP, which is the Workers' Support Fund (FAT) and a portion of the cash deposits, in accordance with Law n. 11,110, of April $25^{\text {th }}$ of 2005.

According to the regulations set out by Resolution n. 4,000 of the CB (CB, 2011), microcredit operations can be carried out with urban and rural entrepreneurs, individuals or companies and independent of the funding. What defines the operation as OPM is the methodology adopted in granting the credit. The same CB resolution also established that the borrower of microcredit can have more than one financing operation in the banking system as long as, in total, they do not exceed 20 thousand reais. The Crescer program was limited to 15 thousand reais per operation.

Crescer aligns with other programs, such as Brazil without Misery, as part of a set of Federal Government policies that aim to create jobs and income, especially in the group of recipients of the Bolsa Familia Program, seeking to help with the emancipation of the families supported. The main change of Crescer in relation to the NOPMP was a reduction in the interest rate, from up to $60 \%$ p.a. to $8 \%$ p.a., and of the OCR, which fell from $3 \%$ to
$1 \%$ on the value of the credit. In addition, the government committed to subsidizing the participants by allocating up to 500 million reais a year for equalization of interest, with resources paid monthly by the National Treasury. The payment of the subsidy was based on the number, value, and timeframe of the operations contracted by the microcredit institutions (MCIs) in general that opted to adhere to the program. For this, the government issued Ordinance n. 271 (July $30^{\text {th }}, 2012$ ) authorizing the Union to grant the aforementioned economic subsidy, with the hope of encouraging the adhesion of private banks and credit unions to Crescer.

In effect, the regulatory changes in microcredit analyzed by this study, especially the reduction of interest rates and the creation of subsidies, could directly and indirectly affect the institutions granting this modality of credit. Specifically, this research investigates the effects of these changes on the (financial and social) performance of the credit unions linked to microcredit.

With regard to the metrics used to measure the financial performance of MFIs, few divergences were found in the papers analyzed. In general, accounting indicators are used, the most classic ones being ROA, ROE, operating cost, and default rate (Armendáriz \& Morduch, 2010; Barry \& Tacneng, 2014; Bédécarrats, Baur \& Lapenu, 2011; Kipesha \& Zhang, 2013).

The groups of indicators analyzed in this study are consistent with the literature referenced, as well as the indicators created by the Social Performance Task Force (SPTF) and summarized by the Microfinance Information Exchange (MIX). The MIX has summarized these aspects into four groups, namely: quality of assets, efficiency and productivity, financial management, and profitability. For the purposes of this research, the data gathered only allowed for those belonging to three of these groups to be analyzed, as it was not possible to construct productivity indicators.

Regarding the MFI social performance measures, only at the start of the 2000s did initiatives emerge to promote the development of tools for measurement and social performance management, the first initiative being that of the SPTF (Bédécarrats et al., 2011). The most widely employed metrics in the previous studies are varied (Borba, 2012; Meyer, 2002; Navajas, Schreiner, Meyer, GonzalezVega \& Rodriguez-Meza, 2000). According to Quayes (2012), the most widely used MFI social performance dimensions are breadth of coverage and depth of coverage of microcredit. Breadth of coverage means making the social benefits of microcredit available for the greatest possible number of clients (Brau \& Woller, 2004; Schreiner \& Yaron, 1999), and depth of coverage relates to how 
much microcredit really reaches "the poorest among the poorest” (Bassem, 2009; Conning, 1999; Hartarska, 2005).

To measure the breadth of coverage, the most widely used variables in the previous studies are: the number of clients covered; the average loan value; and the percentage of female borrowers (Hartarska \& Nadolnyak, 2008; Kar, 2010; Luzzi \& Weber, 2006, 2007; Mersland \& Strøm, 2009; Rosenberg, 2009). As a proxy for the depth of coverage, Quayes (2012) used the average loan size per borrower. This research uses the definitions and some of the proxies for measuring social performance (breadth and depth of coverage) used by Quayes (2012). However, the data available do not allow for the borrowers' gender to be identified.

Considering that credit unions are small or medium sized FIs, it is important to investigate whether and how the new rules affected their financial and social performance. The financial performance and, therefore, the sustainability of the credit unions involved with microcredit could be affected in three aspects: (i) a substantial increase in cost if, as the regulators hoped, consumption microcredit was replaced by productive microcredit, since OPM operations are more expensive due to the credit monitoring technology; (ii) a fall in the revenue from microcredit operations, as a result of the reduction in the interest rate and the OCR; (iii) a change in the default rate, which could fall if the lower interest rates raise the probability of borrowers paying the loan, or increase if there is a sufficiently wide expansion in credit for clients with a poorer risk profile.

Thus, even with the financial rewards offered by the government for operations within the scope of Crescer, it is possible that its net effect on financial performance is negative, if these are not enough to offset potential reductions in revenue, an increase in costs, and increase in defaults.

On the other hand, the new rules are expected to have a positive impact over the number of clients and productive microcredit operations, contributing to the better social performance of credit unions. However, the magnitude of the effect must depend on the impact of Crescer over the financial sustainability of credit unions and over the behavior of other credit market agents, for example public banks and private banks.

The types of institutions that supply microcredit in Brazil range from non-governmental organizations (NGOs) to development banks. It is known that NGOs were not included in the NOPMP. Credit unions act within the NOPMP and Crescer in two different ways: lending directly to the final borrower with their own resources and also as an intermediary, receiving transfers from other FIs via microcredit interfinancial deposits (MIDs).

\section{RESEARCH DESIGN}

This study explores the exogenous shock to the regulatory and institutional environment for microcredit associated with the advent of Crescer in 2011 as a natural experiment. Natural experiments in the area of applied social sciences, in general, are used when some exogenous phenomenon, for example a governmental intervention, changes the institutional environment where individuals, families, companies, and/or municipalities operate (Wooldridge, 2010).

In the microfinance and microcredit segment at a worldwide level, some studies have used the combination of a natural experiment with difference in differences estimations (Cozarenco \& Szafarz, 2014; Ledgerwood, 1999). Yet, in research on microfinance and microcredit in Brazil, this strategy has still barely been explored. One of the studies identified is that of Neri and Medrado (2010), which investigated the impact of the Crediamigo program, of $\mathrm{BNB}$, on access to credit in that region. However, as far as we know, this research is the first to investigate the performance of credit unions that work with microcredit using the difference in differences estimation procedure. The database made available by the $\mathrm{CB}$ is unique and composed of data extracted from the Credit Information System (SCR) and from the Chart of Accounts for Institutions of the National Financial System (COSIF).

\subsection{Characterization of the Population (Treatment Group and Control Group)}

One of the main assumptions of the difference in differences model is that of "parallel trends". This implies that the evolution of the response variables in the treatment and control groups, in the absence of the occurrence of the event of interest, would be similar (parallel), unconditionally or conditioned to the set of control variables included in the estimated model. It is worth mentioning that, for simplicity and following the literature from the area, we used the terms treatment and control to characterize the groups, although they are more suitable for controlled experiments. Under this assumption, it is possible to identify the causal effect of the exogenous event, even if the treatment and control groups differ systematically in various characteristics (Angrist \& Pischke, 2008). So, if the assumption of parallel trends is 
reasonable, it is possible to capture the direct and indirect effects of the changes in the regulatory and institutional environment for microcredit over the financial and social performance of credit unions (Angrist \& Pischke, 2008; Wooldridge, 2010). The direct and indirect impacts for credit unions of the aforementioned changes, especially the reduction in interest rates and the OCR, the creation of subsidies to equalize the rates of those that adhere to the Crescer program, and the strong stimulus for increasing the participation of the public banks in this segment, are identified altogether. It is not possible to identify the effect of each component of the set, since the available data do not allow for the channel responsible for the estimated effect to be isolated.

The credit unions chosen for the treatment group are those that work with microcredit and provided credit in this modality during the period studied. It is important to mention that the credit unions in the treatment group supplied microcredit before the regulatory changes. The control group is composed of the credit unions that did not provide microcredit at any time during the sampling period and, therefore, should not be affected by the event in question.

An indicator of comparability between the groups is the coincidence of the most frequent types of credit unions: both the control and the treatment group contemplate two of the most frequent types, which are free admission credit unions, located in municipalities with up to 300 thousand inhabitants, and rural credit unions. It is worth mentioning that the data on rural credit unions, both those from the Ministry of Employment database and from the $\mathrm{CB}$ database, refer exclusively to the provision of OPM, not including the National Program for Strengthening Family Agriculture (Pronaf). Pronaf is a rural credit program, and rural credit in Brazil has specific legislation and methodologies, which differ from the microcredit analyzed here, which is predominantly urban.
Another reason for the plausibility of the comparison between the groups is the fact that all the credit unions work with various modalities of credit, unlike some MFIs, such as the Civil Society Organizations of Public Interest (OSCIPs) and the Credit Societies for Microentrepreneurs (SCMs), which only operate with microcredit.

Finally, the main similarities between the (treatment and control) groups are: (i) the credit unions are institutions with the same legal nature; (ii) they have the same objectives; (iii) they provide the same types of products and services (credit), fundamentally differing with relation to the modalities of credit provided.

Although the credit unions included in the treatment and control groups are comparable, it is not possible to definitively test the parallel trends assumption. In fact, graphic evaluations and mean equality tests suggest that the evolution of some of the performance indicators used in this research was similar in the two groups of credit unions in the periods before the advent of Crescer, but the results of these diagnostics are not homogenous. For that reason, to reduce the potential for distortion of the inferences as a result of endogeneity problems (in this case, violation of the parallel trends assumption), the main estimated models described below include additional controls. In particular, these models isolate potentially divergent trends in the performance indicators caused by differences in size of the credit unions in the treatment and control groups.

\subsection{Specification of the Empirical Model}

The sample consists of an unbalanced panel, containing 14 semesters with 1,429 credit unions per semester, on average. Ordinary least squares (OLS) and fixed effects (FE) estimators are employed to estimate similar regression models to the one described by equation 1 . This study used six time periods before the event and six after, given that the period studied was from 2008 to 2014 , with half-yearly data.

$$
\begin{gathered}
y_{i t}=\beta_{0}+\beta_{1} C_{R E S C E R}+\beta_{2} M C_{i}+\beta_{3}(M C \times C R E S C E R)_{i t}+\beta_{4} T_{R E N D_{t}} \\
+\beta_{5} L T A P_{i}^{P R E}+\beta_{6}\left(L T A P^{P R E} \times T R E N D\right)_{i t}+u_{i t}
\end{gathered}
$$

In the model above, $y_{i t}$ represents the performance indicator of credit union $i$ in period $t, C R E S C E R_{t}$ is a dummy vairable, such that $C R E S C E R_{t}=0$ in the periods prior to the change in the microcredit environment associated with the advent of the Crescer program (occurring in 2011) and CRESCER $R_{t}=1$ in the periods after the aforementioned change, $M C_{i}$ is a group dummy, such that $M C_{i}=1$ if credit union 1 operates with microcredit and $M C_{i}=0$ otherwise, $(M C \times C R E S C E R)_{i t}$ is the variable of interest and represents the interaction of the two dummies, such that $(M C \times C R E S C E R)_{i t}=1$ only for the credit unions that do microcredit observed in the periods after the regulatory change and $(M C \times C R E S C E R)_{i t}=0$ otherwise, TREND ${ }_{t}, L T A P_{i}^{P R E}$ and $\left(\text { LTAP }^{P R E} \times T^{\text {TREND }}\right)_{i t}$ are control variables. TREND is a deterministic indicator of trend, taking the value from 1 to 14 (semesters), so that its coefficient captures any upward or downward trend in the mean of $y_{i t}$ for the set of credit unions. LTAP ${ }_{i}^{P R E}$ is the natural logarithm of the mean value of the credit portfolio computed in the period prior to the regulatory 
changes. This variable captures preexisting differences in size and volume of the credit operation of the credit unions. $L T A P_{i}^{P R E}$ is systematically greater in the group of credit unions that operate with microcredit. Setting the value of the control variable in the pre-treatment period is important, in this case, because the regulatory changes in microcredit can influence the total volume of credit provided by the credit union in the post-treatment period. For this reason, using $L T A P_{i t}$ would be unsuitable [a case of bad control, as described by Angrist and Pischke (2008)]. The interaction $\left(L T A P^{P R E} \times T R E N D\right)_{i t}$ isolates any different trends in $y_{i t}$ associated with preexisting differences in size and volume of credit of the credit unions. This control may be relevant, since the average size in the period prior to the regulatory changes differs systematically between the treatment and control groups. Finally, $u_{i t}$ is the error term of the model. The parameter of interest is $\beta_{3}$, which captures, under the assumption of parallel trends (conditioned on the control variables), the effect of the regulatory change over the performance of the credit unions that work with microcredit. Different versions of this model were estimated in this research, for example, without control variables or using a complete set of time dummies, as well as the estimation by FE methods instead of estimation by OLS [Wooldridge (2010) discusses the potential gain in efficiency with the use of the FE estimator].

\subsection{Description of the Variables Used}

The dependent variables include the financial performance and social performance indicators of the credit unions described in Table 1 . The indicators of the first group were, based on the literature, divided into three groups: quality of assets, efficiency, and profitability. Social performance, in turn, contemplates two dimensions: breadth of coverage and depth of coverage.

Table 1

Financial and social performance indicators

\begin{tabular}{|c|c|c|}
\hline Group & Indicator & Calculation method \\
\hline \multicolumn{3}{|c|}{ Financial indicators } \\
\hline \multicolumn{3}{|c|}{ Quality of assets } \\
\hline DEF & Defaults - Portfolio at Risk > 90 days & Balance of overdue loans $>90$ days \\
\hline RT_DEF & Rate of default & Balance of overdue loans $>90$ days $\div$ Total active portfolio \\
\hline \multicolumn{3}{|l|}{ Profitability } \\
\hline PROF_PORT & Profitability of credit portfolio & Income from credit operations $\div$ Classified credit portfolio \\
\hline INC_IN & $\begin{array}{l}\text { Income from interest on credit } \\
\text { operations in relation to adjusted total } \\
\text { assets }\end{array}$ & Income from interest on credit operations $\div$ Adjusted total assets (annual) \\
\hline FIN_MARG & Financial intermediation margin & 6-month income from financial intermediation $\div 6$-month operating revenue \\
\hline INCOME_FIN & Income from financial intermediation & Financial intermediation revenues - Financial intermediation expenses \\
\hline INCOME_FIN_IN & $\begin{array}{l}\text { Income from financial intermediation } \\
\text { (interest only) }\end{array}$ & $\begin{array}{l}\text { Financial intermediation revenues - Financial intermediation expenses } \\
\text { (considering only income from interest) }\end{array}$ \\
\hline ROA & ROA - Return on assets & (Net operating income, adjusted - Taxes) $\div$ Adjusted average total assets \\
\hline ROE & ROE - Return on net equity & $\begin{array}{l}\text { (Net operating income, adjusted - Taxes) } \div \text { Adjusted average net income from } \\
\text { the semester }\end{array}$ \\
\hline \multicolumn{3}{|l|}{ Efficiency } \\
\hline OP_MARG & Operating margin & 6 -month operating income $\div 6$-month operating revenue \\
\hline OP_COST & Operating cost & $\begin{array}{l}\text { Administrative expenses } \div \text { (Income from financial intermediation }+ \text { revenue } \\
\text { from services) }\end{array}$ \\
\hline \multicolumn{3}{|l|}{ Social indicators } \\
\hline \multicolumn{3}{|c|}{ Breadth of coverage } \\
\hline CLIEN & Total clients & $\begin{array}{l}\text { Quantity of active clients in the semester by modalities: 1, 2,3,4 and } \\
\text { submodalities } 1303 \text { and } 1304,212 \text {, loans (consumption microcredit) and } \\
403, \text { financing (productive microcredit) }\end{array}$ \\
\hline OPER & Total number of operations & $\begin{array}{l}\text { Quantity of operations carried out in the semester by modalities: 1, 2, 3, } 4 \\
\text { and submodalities } 1303 \text { and } 1304,212 \text {, loans (consumption microcredit) and } \\
403 \text {, financing (productive microcredit) }\end{array}$ \\
\hline \multicolumn{3}{|l|}{ Depth of coverage } \\
\hline ME_CLIEN & $\begin{array}{l}\text { Mean number of operations per } \\
\text { borrower }\end{array}$ & $\begin{array}{l}\text { [Quantity of operations carried out in the semester by modalities: } 1,2,3,4 \\
\text { and submodalities } 1303 \text { and } 1304,212 \text {, loans (consumption microcredit) and } \\
403 \text {, financing (productive microcredit)] } \div \text { Total active clients in the semester }\end{array}$ \\
\hline ME_POR & Mean value per operation & Total active portfolio in the semester $\div$ Quantity of operations in the semester \\
\hline
\end{tabular}

Source: Banco Central do Brasil, Microfinance Information Exchange (MIX) and Quayes (2012). 


\section{ANALYSIS OF RESULTS}

A descriptive analysis of the original data identified a significant set of outliers. To attenuate the influence of extreme observations over the inferences, all the continuous variables were winsorized. This procedure consists of replacing the extreme values, in this case $10 \%$ of the lowest and the highest values, with the values adjacent to the established limit. For some of the variables measured in reais, the logarithmic transformation was also applied, namely: total asset portfolio (TAP); income from financial intermediation (INCOME_FIN); income from financial intermediation considering only interest (INCOME_FIN_IN); and total defaults (DEF). Table 2 presents descriptive statistics of the variables.

\section{Table 2}

Descriptive statistics of the variables

\begin{tabular}{|c|c|c|c|c|c|}
\hline Variable & $\begin{array}{l}\text { Observations* } \\
\text { (n) }\end{array}$ & Mean & Standard deviation & Min. & Max. \\
\hline LTAP & 17,007 & 7.544 & 1.630 & 4.821 & 9.975 \\
\hline \multicolumn{6}{|l|}{ Financial indicators } \\
\hline ROA & 17,006 & 0.089 & 0.091 & -0.036 & 0.261 \\
\hline FIN_MARG & 17,006 & 0.548 & 0.207 & 0.260 & 0.908 \\
\hline OP_MARG & 17,006 & 0.183 & 0.178 & -0.077 & 0.521 \\
\hline OP_COST & 17,007 & 0.719 & 0.259 & 0.354 & 1.219 \\
\hline PORT_PROF & 17,007 & 0.123 & 0.038 & 0.067 & 0.193 \\
\hline ROE & 17,007 & 0.271 & 0.242 & -0.100 & 0.702 \\
\hline INC_IN & 17,007 & 0.358 & 0.169 & 0.132 & 0.654 \\
\hline INCOME_FIN & 16,670 & 5.363 & 1.367 & 3.187 & 7.482 \\
\hline INCOME_FIN_IN & 16,682 & 5.384 & 1.369 & 3.211 & 7.514 \\
\hline DEF & 15,163 & 3.767 & 1.692 & 1.024 & 6.363 \\
\hline RT_DEF & 17,007 & 0.027 & 0.029 & 0.000 & 0.095 \\
\hline \multicolumn{6}{|l|}{ Social indicators } \\
\hline CLIEN & 16,994 & $1,966.98$ & $2,169.21$ & 202 & 7.020 \\
\hline OPER & 16,994 & $3,439.68$ & $3,933.73$ & 278 & 12.477 \\
\hline ME_CLIEN & 16,994 & 1.672 & 0.958 & 1.000 & 3.959 \\
\hline ME_POR & 16,993 & 7.428 & 1.463 & 5.106 & 9.690 \\
\hline
\end{tabular}

The sample covers all the credit unions of the National Financial System with information available for the period from 2008 to 2014 , in semesters, totaling 1,429 credit unions observed for 14 semesters. The variables INCOME_FIN, INCOME_FIN_IN, and DEF were transformed by logarithm. All the variables were winsorized at $10 \%$. The nominal variables were deflated by the Consumer Price Index (IPCA) [Brazilian Institute of Geography and Statistics (IBGE)].

CLIEN = total clients; OP_COST = operating cost; DEF = log of defaults - portfolio at risk $>90$ days; LTAP = log of the portfolio of loan assets (control variable); FIN_MARG = financial intermediation margin; $O P \_M A R G=$ operating margin; $M E \_P O R=$ mean value per operation; ME_CLIEN = mean number of operations per borrower; $O P E R=$ total operations; INCOME_IN = income from interest on credit operations in relation to adjusted total assets; PROF_PORT = profitability of the credit portfolio; INCOME_FIN = log of income from financial intermediation; INCOME_FIN_IN = log of income from financial intermediation (only considering interest); $R O A$ - return on assets; $R O E$ - return on net equity; $R T \_D E F=$ rate of default.

* Number of credit unions multiplied by the number of time periods.

Source: Elaborated by the authors.

It is observed that the mean financial intermediation margin (FIN_MARG) is greater than the operating margin $\left(O P \_M A R G\right)$, recording 0.548 and 0.183 , respectively; both are lower than the operating cost (OP_COST), which presents a mean of 0.719 and standard deviation of 0.259 . The mean income from interest (INCOME_IN) is 0.358 , which in turn represents $6.67 \%$ of the income from financial intermediation (INCOME_FIN), which is 5.363 and $6.64 \%$ of the mean for the variable INCOME_FIN_IN (income from financial intermediation considering only interest), which is 5.384 . 
Regarding the social indicators, the mean number of clients (CLIEN) is $1,966.98$, with a standard deviation of 2,169.21; the mean number of operations (OPER) is $3,439.68$, with a standard deviation of $3,933.73$. The mean number of operations per borrower is 1.672 , with a standard deviation of 0.958 .

Tables 3 and 4 report the estimates based on equation 2, using the FE estimator.

$$
y_{i t}=\delta_{0}+\delta_{1}(M C \times C R E S C E R)_{i t}+\delta_{2}\left(L T A P^{P R E} \times T R E N D\right)_{i t}+c_{i}+\sum_{j=2}^{14} \alpha_{j} S E M_{j t}+\varepsilon_{i t}
$$

In this specification, the variables shown in equation 1 , which do not vary in time $\left(M C_{i}\right.$ and $\left.L T A P_{i}^{P R E}\right)$, are suppressed by the intragroup transformation used to eliminate $c_{i}$, a term that represents the unobserved heterogeneity of credit union $i$ (i.e., credit unions fixed effects). In turn, $c_{i}$ captures the association between the mean of $y_{i t}$ and any characteristics of the credit unions that did not vary during the sampling period. Similarly, the variables that do not vary between credit unions (CRESCER $R_{t}$ and TREND) are excluded as they are perfectly collinear with the set of semester dummies
$S E M_{j t} j=1, \ldots, 14$ (in practice, since the model includes an intercept, the first semester dummy is also excluded from the regressions). The coefficient of interest in this model is represented by $\delta_{1}$, which has the same interpretation of $\beta_{3}$ in equation 1 . Again, the interaction $\left(L T A P^{P R E} \times T R E N D\right)_{i t}$ captures any differences in trend in $y_{i t}$ associated with preexisting differences in size and volume of credit of the credit unions. To save space, tables 2 and 3 only report the coefficient of interest $\delta_{1}$, estimated in regressions represented by equation 2 , using each one of the indicators described in Table 1 as a response variable.

\section{Table 3}

Regression based on equation 2 - Financial indicators

\begin{tabular}{|c|c|c|c|c|}
\hline Response variable & $\begin{array}{c}\text { Coefficient } \\
(M C \times C R E S C E R)\end{array}$ & $\begin{array}{l}\text { Observations } \\
\text { (n) }\end{array}$ & $\begin{array}{l}\text { Credit Unions } \\
\text { (n) }\end{array}$ & R-sq. \\
\hline \multicolumn{5}{|l|}{ Quality of assets } \\
\hline Defaults (DEF) & $\begin{array}{l}0.131^{*} \\
(0.072)\end{array}$ & 15,019 & 1,330 & 0.035 \\
\hline Rate of default (RT_DEF) & $\begin{array}{r}-0.0007 \\
(0.001)\end{array}$ & 16,837 & 1,392 & 0.003 \\
\hline \multicolumn{5}{|l|}{ Profitability } \\
\hline $\begin{array}{l}\text { Profitability of the credit portfolio (PROF_ } \\
\text { PORT) }\end{array}$ & $\begin{array}{c}-0.003^{* *} \\
(0.001)\end{array}$ & 16,837 & 1,392 & 0.075 \\
\hline Income from interest on assets (INCOME_IN) & $\begin{array}{l}-0.008 \\
(0.007)\end{array}$ & 16,837 & 1,392 & 0.050 \\
\hline Financial intermediation margin (FIN_MARG) & $\begin{array}{c}0.002 \\
(0.006)\end{array}$ & 16,836 & 1,392 & 0.003 \\
\hline $\begin{array}{l}\text { Income from financial intermediation } \\
\text { (INCOME_FIN) }\end{array}$ & $\begin{array}{c}0.046 \\
(0.038)\end{array}$ & 16,511 & 1,386 & 0.024 \\
\hline $\begin{array}{l}\text { Income from financial intermediation (interest) } \\
\text { (INCOME_FIN_IN) }\end{array}$ & $\begin{array}{c}0.057 \\
(0.038) \\
\end{array}$ & 16,522 & 1,386 & 0.027 \\
\hline Return on assets (ROA) & $\begin{array}{l}-0.002 \\
(0.004)\end{array}$ & 16,836 & 1,392 & 0.010 \\
\hline Return on net equity (ROE) & $\begin{array}{l}-0.001 \\
(0.014)\end{array}$ & 16,837 & 1,392 & 0.026 \\
\hline \multicolumn{5}{|l|}{ Efficiency } \\
\hline Operating margin (OP_MARG) & $\begin{array}{l}0.011^{* *} \\
(0.005)\end{array}$ & 16,836 & 1,392 & 0.006 \\
\hline Operating cost (OP_COST) & $\begin{array}{l}-0.012 \\
(0.009)\end{array}$ & 16,837 & 1,392 & 0.049 \\
\hline
\end{tabular}

This table shows the results of estimations of equation 2 using the fixed effects (FEs) estimator. The response variables are described in Table 1. To save space, the table only reports the estimates for the coefficient of interest, associated with the interaction $(M C \times C R E S C E R)_{i t}\left(\delta_{1}\right.$ in equation 2$)$. All the continuous variables were winsorized and the nominal variables were deflated by the Consumer Price Index (IPCA) [Brazilian Institute of Geography and Statistics (IBGE)]. Standard errors Clustered by credit union, asymptomatically robust to arbitrary forms of autocorrection and heteroskedasticity, are reported in parentheses. $*, * *, * * *=$ statistical significance at the $10 \%, 5 \%$, and $1 \%$ levels, respectively.

Source: Elaborated by the authors. 
Considering the indicators related to the quality of the assets, Table 3 shows a significant increase in the balance of loans overdue by more than 90 days (DEF) for the credit unions that work with microcredit (treatment group) in comparison with those that do not work with microcredit (control group) in the period after the changes associated with Crescer. However, the default rate (loans overdue by more than 90 days divided by the total active portfolio) evolves in a similar way for the two groups in the periods before and after the event, as the estimate for the coefficient $\delta_{1}$ close to 0 shows, with a $t$ statistic equally close to 0 . These combined results are compatible with the hypothesis that the volume of credit provided by the credit unions in the control group increased as a result of the implementation of Crescer, and for this reason their total defaults also increased. Therefore, there is evidence that Crescer positively influenced the provision of microcredit without simultaneously causing a relevant deterioration in the quality of the credit portfolio of the credit unions.

Regarding the profitability of the credit unions, of the seven indicators evaluated, only one appears to have been significantly affected by the changes in the microcredit environment. Specifically, it is observed that the profitability of the credit portfolio decreases in the post-treatment period for the credit unions that work with microcredit in comparison with other credit unions. In light of the inferences about the quality of the assets discussed here, this result suggests that the volume of credit grew more quickly than the income from credit operations, possibly due to the lower interest rates associated with microcredit operations. However, the lack of statistical significance of the estimates at the conventional levels, associated with the other profitability indicators, suggests that any negative impact of the regulatory changes over the profitability of the credit unions is unclear or not very relevant, possibly because the volume of operations linked to the new rules is not enough to affect the overall financial performance of the credit unions. In particular, the estimates of $\delta_{1}$ (and its $t$ statistic) obtained when ROA or ROE is used as a response variable are close to 0 .

The results shown in Table 3 are compatible with an increase in the efficiency of the credit unions associated with the advent of Crescer. In particular, the significant increase in the operating margin (positive estimated coefficient significant at the $5 \%$ level) suggests that the mean operating revenue of the treatment group grew more than its operating expenses in comparison with the control group. When the response variable is the operating cost indicator (administrative expenses divided by the income from financial intermediation and revenue from services), the estimate of the coefficient of interest is negative, but not significant at the conventional levels.

Table 4

Regressions based on equation 2 - Social indicators

\begin{tabular}{lccc}
\hline Response variable & $\begin{array}{c}\text { Coefficient } \\
(\text { MC } \times \text { CRESCER })\end{array}$ & $\begin{array}{c}\text { Observations } \\
(\mathbf{n})\end{array}$ & $\begin{array}{c}\text { Credit Unions } \\
(\mathbf{n})\end{array}$ \\
\hline Breadth of coverage & $\begin{array}{c}479.61^{* * *} \\
(115.02)\end{array}$ & 16,824 & 1,392 \\
\hline Total clients (CLIEN) & $\begin{array}{c}1421.48^{* * *} \\
(204.29)\end{array}$ & 16,824 & 1,392 \\
\hline Total operations (OPER) & & & 0.338 \\
\hline Depth of coverage & $\begin{array}{c}0.072 \\
(0.050)\end{array}$ & 16,824 & 1,392 \\
\hline $\begin{array}{l}\text { Operations per borrower } \\
\text { (n) (ME_CLIEN) }\end{array}$ & $\begin{array}{c}-0.0004^{*} \\
(0.0002)\end{array}$ & 16,823 & 0.034 \\
\hline $\begin{array}{l}\text { Mean value per operation } \\
\text { (ME_POR) }\end{array}$ & & 1,392 & 0.262 \\
\hline
\end{tabular}

This table shows the results of estimations of equation 2 using the fixed effects (FEs) estimator. The response variables are described in Table 1. To save space, the table only reports the estimates for the coefficient of interest, associated with the interaction $(M C \times C R E S C E R)_{i t}\left(\delta_{1}\right.$ in equation 2). All the continuous variables were winsorized and the nominal variables were deflated by the Consumer Price Index (IPCA) [Brazilian Institute of Geography and Statistics (IBCE)]. Standard errors Clustered by credit union, asymptomatically robust to arbitrary forms of autocorrelation and heteroskedasticity, are reported in parentheses. $*, * *, * *=$ statistical significance at $10 \%, 5 \%$, and $1 \%$, respectively.

Source: Elaborated by the authors.

Table 4 reports the results of the estimations using four social performance indicators. The first two relate to the breadth of coverage of the credit unions, focusing on the total number of clients (CLIEN) and the total number of credit operations (OPER), including microcredit and the other modalities offered by the institutions. In both 
cases, the estimates suggest a positive and economically and statistically relevant impact (the estimated coefficient of interest is significant at the $1 \%$ level in all cases) of the regulatory changes associated with the Crescer program. The specification of the regressions (equation 2) ensures that this result is not due to previous differences in average size or volume of the portfolio of the treatment and control groups, nor to different growth trends for the response variables associated with previous differences in credit union size. The results therefore suggest that the Crescer program caused a significant increase in the number of clients and operations of the credit unions linked to microcredit.

The depth of coverage indicators, on the other hand, focus on the relationship between the quantity of credit operations and the total number of clients (ME_CLIEN) and the relationship between the total value of the portfolio and the quantity of credit operations (ME_POR). In the second case, the negative estimate significant at the $10 \%$ level for the coefficient of interest suggests that Crescer contributed to the quantity of credit operations increasing more quickly than the total value of the credit portfolio, which is a compatible result with a reduction in the average size of the credit operations caused by the provision of lower value loans. On the other hand, there is no evidence that the expansion in the number of clients was more accelerated than the expansion in the number of operations, based on the result of the estimation using ME_CLIEN as a response variable (in fact, the positive estimation reported in the table suggests the opposite, although it is not statistically significant at the conventional levels). Therefore, it is unclear that the regulatory changes caused the credit unions that work with microcredit to expand their provision of credit to poorer clients (alternatively, the results suggest that, on average, the clients of these institutions may have had access to a greater number of lower value loans).

\section{CONCLUSIONS}

This research investigates the impact of the regulatory changes implemented in microcredit in 2011 over the financial and social performance of Brazilian credit unions. The results suggest that the volume of clients and of credit operations was positively affected by the changes analyzed. There is evidence of a reduction in the average value of the operations, as could be expected from an expansion concentraded in microcredit operations. On the other hand, there is no evidence that the increase in the volume of credit benefited poorer clients, although the data do not allow for this hypothesis to be tested directly. Therefore, the social performance of the credit unions that work with microcredit appears to have been positively affected but more so in the breadth dimension than in the depth of coverage dimension.

Despite the significant growth in credit operations and number of clients and the reduction in the average value of the operations, there is no evidence of a deterioration in the quality of the credit portfolio of the credit unions, measured by its default rate. There is also no clear evidence that the profitability of the credit unions was affected by the event. Of the seven indicators evaluated, in only one is the coefficient of interest significant at the conventional levels in this case, suggesting that the volume of credit grew more quickly than the income from credit operations, which is a compatible result with the charging of lower interest rates in the microcredit operations. On the other hand, there is evidence that operating revenues grew more quickly than operating expenses, suggesting that the changes did not cause a loss in efficiency for the credit unions that work with microcredit. Taken together, these results suggest that the governmental intervention in question did not compromise the financial sustainability of the credit unions.

Although unreported descriptive analyses suggest that the credit unions included in the treatment and control groups are comparable, the uncertainty regarding the validity of the parallel trends assumption suggests caution in the causal inferences. It should also be mentioned that the credit unions choose whether to offer microcredit in the context of the NOPMP and Crescer programs or not. The credit unions that adhere possibly saw in these programs the opportunity to better achieve their social objectives, by increasing their provision of microcredit using their own resources, captured directly or derived from transfers. The absence of evidence of a deterioration in the financial sustainability of these institutions also suggests that, on average, the expansion of their operations took place in a cautious way, which is compatible with the low share of the segment in the total volume of microcredit operations carried out in Brazil.

Naturally, the results and conclusions of this research are limited by the information available. In particular, the databases used do not allow for a detailed analysis of how the credit operations are allocated into their various modalities and which publics are served by them. Future studies could complement the analysis presented here, by investigating in more depth the impact of microcredit on the communities that benefit from it, based on primary data produced via a questionnaire or in qualitative field research. 


\section{REFERENCES}

Aghion, B. A. de, \& Morduch, J. (2005). The economics of microfinance (2nd ed.). Cambridge: MIT Press.

Angrist, J. D. \& Pischke, J. S. (2008). Mostly harmless econometrics: An empiricist's companion. New Jersey: Princeton University Press.

Armendáriz, B., \& Morduch, J. (2010). The economics of microfinance (2nd ed.). London: MIT Press.

Banco Central do Brasil. (2011). Resolution n. 4,000, of August $25^{\text {th }}$ of 2011. Alters and consolidates the norms that discuss carrying out microcredit operations aimed at the low income population and microentrepreneurs. Retrieved from https://www.bcb.gov. $\mathrm{br} / \mathrm{pre} /$ normativos/busca/downloadNormativo.asp?arquivo=/ Lists/Normativos/Attachments/49342/Res_4000_v1_O.pdf.

Barone, F. M., \& Sader, E. (2008). Acesso ao crédito no Brasil: evolução e perspectivas. Revista de Administração Pública, 42(6), 1249-1267.

Barry, T. A., \& Tacneng, R. (2014). The impact of governance and institutional quality on MFI outreach and financial performance in Sub-Saharan Africa. World Development, 58, 1-20.

Bassem, B. S. (2009). Governance and performance of microfinance institutions in Mediterranean countries. Journal of Business Economics and Management, 10(1), 31-43.

Bastelaer, T. V. (2000). Does social capital facilitate the poor's access to credit? A review of the microeconomic literature [Working Paper]. The World Bank Social Capital Initiative.

Bédécarrats, F., Baur, S., \& Lapenu, C. (2011). Combining social and financial performance: A paradox? Paper presented at the Global Microcredit Summit. Valladolid.Retrieved from http://www.microcreditsummit.org/ resource/23/combining-social-and-financial-performance. html.

Borba, P. da R. F. (2012). Relação entre desempenho financeiro e desempenho social de instituições de microfinanças na América Latina (Doctoral Thesis). Universidade de São Paulo, São Paulo.

Brau, J. C., \& Woller, G. M. (2004). Microfinance: A comprehensive review of the existing literature. Journal of Entrepreneurial Finance, 9(1), 1-27.

Christen, R. P., \& Rosenberg, R. (2000). The rush to regulate: Legal frameworks for microfinance. CGAP Occasional Paper [Working Paper]. World Bank.

Conning, J. (1999). Outreach, sustainability and leverage in monitored and peer-monitored lending. Journal of Development Economics, 60(1), 51-77.

Cozarenco, A., \& Szafarz, A. (2014). Microcredit in developed countries: unexpected consequences of loan ceilings [Working Paper]. Centre Emile Bernheim.

Cull, R., Demirgüç-Kunt, A., \& Morduch, J. (2008). Microfinance meets the market. Journal of Economic Perspectives, 23(1), 167-192

Gonzalez, L., Diniz, E. H., \& Pozzebon, M. (2015). The value of proximity finance: How the traditional banking system can contribute to microfinance. Innovations, 10(1-2), 125-137.

Gonzalez, L., Righetti, C., \& Di Serio, L. C. (2014). Microcrédito e impacto sobre a geração de renda: o caso do Banco Real. Revista de Economia Contemporânea, 18(3), 453-476.
Hartarska, V. (2005). Governance and performance of microfinance institutions in Central and Eastern Europe and the Newly Independent States. World Development, 33(10), 1627-1643.

Hartarska, V., \& Nadolnyak, D. (2008). An impact analysis of microfinance in Bosnia and Herzegovina. World Development, 36(12), 2605-2619.

Kar, A. K. (2010). Sustainability and mission drift in microfinance (Doctoral Thesis). Hanken School of Economics, Helsinki.

Kipesha, E. F., \& Zhang, X. (2013). Sustainability, profitability and outreach tradeoffs: evidences from microfinance institutions in East Africa. European Journal of Business and Management, 5(8), 136-149.

Lauer, K., \& Staschen, S. (2013). Regulation. In J. Ledgerwood, J. Earne, \& C. Nelson (Eds.), The new microfinance handbook: A financial market system perspective (pp. 413-436).

Washington D. C.: International Bank for Reconstruction and Development/The World Bank.

Ledgerwood, J. (1999). Microfinance handbook: An institutional and financial perspective. Washington D. C.: International Bank for Reconstruction and Development/The World Bank.

Law n. 11,110, of April 25 $5^{\text {th }}$ of 2005. (April 26th, 2005). Establishes the National Oriented Productive Microcredit Program NOPMP and alters arrangements of Law n. 8,029, of April $12^{\text {th }}$ of 1990 , which discusses the extinction and dissolution of entities of the federal public administration; of Law n. 9,311, of October $24^{\text {th }}$ of 1996 , which establishes the Provisional Contribution on Movement or Transmission of Values and Credits and Rights of a Financial Nature - CPMF; of Law n. 9,872 , of November $23^{\text {rd }}$ of 1999 , which creates the Guarantee Fund for the Creation of Jobs and Income - FUNPROGER; of Law n. 10,194, of February $14^{\text {th }}$ of 2001 , which discusses the establishment of Credit Societies for Microentrepreneurs; and of Law n. 10,735 , of September $11^{\text {th }}$ of 2003 , which discusses directing cash deposits captured by financial institutions toward credit operations aimed at the low income population and microentrepreneurs; and makes other arrangements. Retrieved from http://www2.camara.leg.br/legin/fed/lei/2005/ lei-11110-25-abril-2005-536683-publicacaooriginal-27600-pl. html.

Law n. 12,613, of April $18^{\text {th }}$ of 2012. (April 19 $9^{\text {th }}, 2012$ ). Alters Law n. 10,735 , of September $11^{\text {th }}$ of 2003 , which discusses directing cash deposits captured by financial institutions toward credit operations aimed at the low income population and microentrepreneurs, and makes other arrangements. Retrieved from http://www.planalto.gov.br/ccivil_03/_ Ato2011-2014/2012/Lei/L12613.htm.

Law n. 12,666, of June $14^{\text {th }}$ of 2012 (June $15^{\text {th }}, 2012$ ). Alters Law n. 11,110 , of April $25^{\text {th }}$ of 2005 , to authorize the Union to grant an economic subsidy, in the form of equalization of part of the costs that financial institutions are subject to for contracting and monitoring oriented productive microcredit operations; authorizes the granting of an economic subsidy, under the modality of interest rate equalization, in financing operations for alcohol fuel storage; alters Law n. 10,453, of May $13^{\text {th }}$ of 2002; and makes other arrangements. Retrieved from http:// www.planalto.gov.br/ccivil_03/_Ato2011-2014/2012/Lei/ L12666.htm. 
Littlefield, E., Morduch, J., \& Hashemi, S. (2003). Is microfinance an effective strategy to reach the Millennium Development Goals? Focus Note, 24(2003), 1-11.

Luzzi, G. F., \& Weber, S. (2006). Measuring the performance of microfinance institutions. Retrieved from https://dx.doi. org/10.2139/ssrn.918750.

Luzzi, G. F., \& Weber, S. (2007). Measuring the performance of MFIs: An application of factor analysis. In B. Balkenhol (Ed.), Microfinance and Public Policy (pp. 153-170). London: Palgrave Macmillan.

Macchiavello, E. (2012). Microfinance Regulation and Supervision: a multi-faced prism of structures, levels and issues. NYU Journal of Law and Business, 9(125), 125-197.

Martins, P. H., Winograd, A., \& Salles, R. C. (2002). Manual de Regulamentação das Microfinanças: Programa de Desenvolvimento Institucional. Rio de Janeiro: Banco Nacional de Desenvolvimento Econômico e Social.

Meagher, P. (2002). Microfinance regulation in developing countries: A comparative review of current practice. Retrieved from https://www.microfinancegateway.org/sites/default/ files/mfg-en-paper-microfinance-regulation-in-developingcountries-a-comparative-review-of-current-practice-2002.pdf.

Mersland, R., \& Strøm, R. Ø. (2009). Performance and governance in microfinance institutions. Journal of Banking \& Finance, 33(4), 662-669.

Meyer, R. L. (2002). The demand for flexible microfinance products: lessons from Bangladesh. Journal of International Development, 14(3), 351-368.

Miguel, A. C. (2012). Microcrédito no Brasil: uma agenda de política pública para o mercado de microfinanças. REDD Revista Espaço de Diálogo e Desconexão, 4(2), 1-23.

Morduch, J. (1999). The microfinance promise. Journal of Economic Literature, 37(4), 1569-1614.

Navajas, S., Schreiner, M., Meyer, R. L., Gonzalez-Vega, C., \& Rodriguez-Meza, J. (2000). Microcredit and the poorest of the poor: theory and evidence from Bolivia. World Development, 28(2), 333-346.

Neri, M., \& Medrado, A. (2010). Experimentando microcrédito: uma análise de impacto do Crediamigo no acesso a crédito. Documentos Técnico-Científicos, 41(1), 133-154.

Ordinance n. 271. (July $30^{\text {th }}, 2012$ ) Art. $1^{\circ}$ Observing the limits and other conditions established by the National Monetary Council and by this Ordinance, the payment of equalization of financial charges is authorized on the average daily balances of loans granted by the National Bank for Economic and Social Development - BNDES, with its own resources. Retrieved from http://fazenda.gov.br/acesso-a-informacao/ institucional/legislacao/portarias-ministeriais/2012/portariano.-271-de-30-de-julho-de-2012.

Ordinance $n .411$. (July $17^{\text {th }}, 2013$ ). Art. 1 Obeying the conditions, criteria, and limits established by Law n. 11,110, of April $25^{\text {th }}$ of 2005 , by Decree n. 5,288 , of November $29^{\text {th }}$ of 2004 , and by National Monetary Council Resolution - CMN n. 4,000 , of August $25^{\text {th }}$ of 2011 , and subsequent alterations, this authorizes the payment of equalization of part of the costs to which financial institutions are subject for contracting and monitoring oriented productive microcredit operations contracted between June $1^{\text {st }}$ of 2013 and December $31^{\text {st }}$ of 2013 , as long as the following conditions are observed: Retreived from http://www.fazenda.gov.br/ acesso-a-informacao/institucional/legislacao/portariasministeriais/2013/portaria-no.-411-de-10-de-julho-de-2013.

Ordinance n. 83 (March $31^{\text {st }}, 2014$ ). Establishes as conditions for payment of equalization of the Crescer program without the scope of the National Oriented Productive Microcredit Program - NOPMP for the 2014 financial period. Retrieved from http://www.fazenda.gov.br/acesso-a-informacao/ institucional/legislacao/portarias-ministeriais/2014/portariano-83-de-21-de-marco-de-2014-1.

Provisional Measure $n$. 543. (August 25 ${ }^{\text {th }}, 2011$ ). Alters Law $n$. 11,110 , of April 25 $5^{\text {th }}$ of 2005 , to authorize the Union to grant financial institutions an economic subsidy in the form of equalization of part of the costs they are subject to, to contract and monitor oriented productive microcredit operations. Retreived from http://www2.camara.leg.br/legin/fed/ medpro/2011/medidaprovisoria-543-24-agosto-2011-611340publicacaooriginal-133479-pe.html.

Quayes, S. (2012). Depth of outreach and financial sustainability of microfinance institutions. Applied Economics, 44(26), 34213433.

Railienè, G., \& Sinevičienė, L. (2015). Performance valuation of credit unions having social and self-sustaining aim. ProcediaSocial and Behavioral Sciences, 213(2015), 423-429.

Rosales, R. (2000). Marco jurídico para as instituições de microcrédito. In: Seminário Internacional BNDES Microfinanças (pp. 1-20). Rio de Janeiro: Banco Nacional de Desenvolvimento Econômico e Social.

Rosenberg, R. (2009). Measuring results of microfinance institutions: Minimum indicators that donors and investors should track - A technical guide. CGAP Technical Guide. Retrieved from http://www.cgap.org/publications/measuringresults-microfinance-institutions-minimum-indicators.

Schreiner, M., \& Yaron, J. (1999). The subsidy dependence index and recent attempts to adjust it. Savings and Development, 23(4), 375-405.

Schroder, M. (2005). Finanças, comunidades e inovações: organizações financeiras da agricultura familiar - O Sistema Cresol (1995-2003) (Doctoral Thesis). Instituto de Economia, Universidade Estadual de Campinas, Campinas.

Secretaria de Política Econômica. (2012). Relatório de gestão do exercício de 2011. Brasília: Ministério da Fazenda.

Shadish, W. E., Cook, T. D., \& Campbell, D. T. (2002). Experimental and quasi-experimental designs for generalized causal inference. Boston: Houghton Mifflin.

Soares, M. M., \& Melo Sobrinho, A. D. (2008). Microfinanças: o papel do Banco Central do Brasil e a importância do cooperativismo de crédito ( $2^{\text {nd }}$ ed.). Brasília: Banco Central do Brasil.

Ward, A. M., \& McKillop, D. G. (2005). An investigation into the link between UK credit union characteristics, location and their success. Annals of Public and Cooperative Economics, 76(3), 461-489.

Wooldridge, J. M., (2010). Econometric analysis of cross section and panel data ( $2^{\text {nd }}$ ed.). Cambridge: MIT Press. 